\title{
Offshore Flight of Buffleheads, Bucephala albeola, After Twilight in Winter: An Anti-Predation Tactic?
}

\author{
JAMES K. FINLEY \\ 10232 Summerset Place, Sidney, British Columbia V8L 4X2 Canada
}

Finley, James K. 2007. Offshore flight of Buffleheads, Bucephala albeola, after twilight in winter: an anti-predation tactic? Canadian Field-Naturalist 121(4): 375-378.

In winter, on Vancouver Island, Buffleheads depart from coastal marine feeding habitat shortly after the onset of civil twilight. This precisely-timed phenomenon may have evolved in response to predation pressure from Peregrine Falcons, Falco peregrinus. The dual habitat requirements of Buffleheads in Shoal Harbour Migratory Bird Sanctuary (1931) and Sidney Channel Important Bird Area are to be included within the proposed Gulf Islands National Marine Conservation Area.

Key Words: Bufflehead, Bucephala albeola, timing, crepuscular flight, anti-predation, dual habitats, British Columbia.

Time, timing and habitat structure are key elements in the evolution of anti-predation behaviour. Many species' behaviours are synchronized with shifting light levels to reduce the risk of attack. Genetic clocks are set by aeons of predatory pressure.

At least since the Pleistocene, Buffleheads (Bucephala albeola) have returned from their interior breeding grounds to limited marine wintering habitat on the east and west coasts of North America (Erskine 1972; Gauthier 1993). A large portion of the western population winters in coastal waters of the Strait of Georgia and Puget Sound (Salish Sea) where they occupy sheltered coves like Shoal Harbour Migratory Bird Sanctuary, on the southeastern coast of Vancouver Island (Dawe $1982 *)$. Established in 1931, the sanctuary includes inter-tidal mudflats that support high densities of benthic invertebrates, prime feeding habitat (when covered with water) for Buffleheads. Buffleheads feed intensively during the day but what they do at night is largely unknown. Here, I document a precisely timed phenomenon, the Bufflehead's offshore flight after twilight.

\section{Methods}

This study was conducted from my home observatory in Sidney, British Columbia, overlooking Shoal Harbour Migratory Bird Sanctuary on southeastern Vancouver Island, adjacent to Sidney Channel "Important Bird Area" and the new Gulf Islands National Park Reserve (Figure 1). My bay-window overlooks Roberts Bay, a rich inter-tidal mud flat, prime Bufflehead habitat from mid-October to early May. Monthly surveys of the sanctuary have been conducted since 2000 as part of the Coastal Waterbird Surveys, a citizen-based monitoring initiative of Bird Studies Canada and the Canadian Wildlife Service, Environment Canada (Badzinski et al. 2006).

Casual observations occurred every day between October and May, from my vantage 4-6 m above sea level, with a westerly view such that Buffleheads can be seen in silhouette at dusk, and against background res- idential lighting. Observations of their departure time (Pacific Standard Time) were recorded opportunistically between January and May in $2000(n=29), 2004$ $(n=15), 2005(n=12)$ and $2007(n=5)$. Typically the flock departed in waves close together and departure time was recorded to the nearest minute. Sometimes, especially toward spring, departure was spread out over several minutes, though the majority of birds typically departed en masse. In such cases, the median departure time, when the majority left, was used in the analyses. Data were entered on a computer spreadsheet along with a table on sunset and twilight times for latitude $48^{\circ} \mathrm{N}$ (Victoria). Regression analysis was performed with Microsoft Excel software.

Civil twilight is defined when the sun is 3 degrees below the horizon and there is sufficient illumination, in clear conditions, for the average human eye to distinguish terrestrial objects, and the horizon remains distinct (U.S. Naval Observatory website). Nautical twilight occurs when the sun is 6 degrees below the horizon, the general outlines of objects may be distinguishable, and the horizon is indistinct.

\section{Results}

The late winter (January to March) population of Buffleheads on Roberts Bay was relatively stable at $130 \pm$ S.D. 33, $n=16$. Typically, around sunset, these birds began to gather near the southwestern shore, especially around the delta of Mermaid Creek, where they engaged in social activity and preening before coming to a rest, heads tucked, tails erect. During the brief rest period, the flock was often arrayed in lines near shore, facing offshore, with a few alert individuals. Imminent departure was often evident by abrupt alertness of the flock, followed by swimming toward the mouth of the bay. Small groups or pairs sometimes departed in advance of the main movement, but typically, the flock departed close together, about 10-12 minutes after the onset of civil twilight, before the onset of nautical twilight. The slope of the departure regression 
line parallels the seasonal advance of civil twilight (Figure 2). One exception fell significantly before the twilight threshold; this occurred on 3 February 2007 when the flock departed 27 minutes earlier than expected.

\section{Discussion}

The offshore departure of Buffleheads after civil twilight is a precisely timed phenomenon, presumably set by their genetic clock, and hormonally mediated by the pineal gland (Welty 1975). Undoubtedly some of the variation was due to the effects of cloud cover; a more precise correlation could likely have been obtained if a light meter had been used. Surprisingly, there is no mention of this daily scheduling activity in the literature (Munro 1942; Erskine 1972; Gauthier 1993), nor of similar behaviour in the waterfowl literature, although it is generally recognized that waterfowl tend to fly around sunset. Perhaps their daily flight has been overlooked because most biologists are sitting down to supper and the news, or - maybe more so - because we live by the clock and tend to take such scheduling for granted.

Buffleheads appear to be obligatory nocturnal migrants, famous for their crash on 4 November 1940, caused by unusual weather and artificial lighting conditions in Saskatchewan (Swallow 1941; Erskine 1972; Finley 2001; Eyolfson 2006). Nocturnal migration, timed to coincide with favourable tailwinds and clear skies, may have evolved due to the energetic demands of the Bufflehead's small size and their need to feed during daylight. This physiological factor in long-range migration appears irrelevant to their daily schedule, although in both cases their flight is initiated after sunset. Perhaps their daily offshore flight is an anti-predation tactic.

Three predators, River Otters, Enhydra lutra, Peregrine Falcons, Falco peregrinus, and Bald Eagles, Haliaeetus leucocephalus, prey on Buffleheads on their west coast wintering grounds. Buffleheads are highly vigilant for otters, and distinguish them from Harbour Seals (Phoca vitulina). Most successful predation attempts that I've observed have involved otters, often a couple of times each season, usually in rough seas, and at any time of day though perhaps more frequently in low light conditions. If Buffleheads are more vulnerable to otters in low light, one would expect that they would depart from coastal waters well before twilight.

All other successful attempts have involved the resident pair of eagles, which overfly the sanctuary throughout the day. Bald Eagles take the occasional Bufflehead by either surprising them, or hovering and forcing them to tire; however, this is a demanding strategy, not often seen. Though mildly alert to their flights, Bufflehead do not normally take evasive action unlike the resident Wigeon (Anas americana). Yet eagles can be effective predators; just this past December, the pair, working in tandem, took two in succession within an hour. It seems that they take primarily juveniles and weak birds,

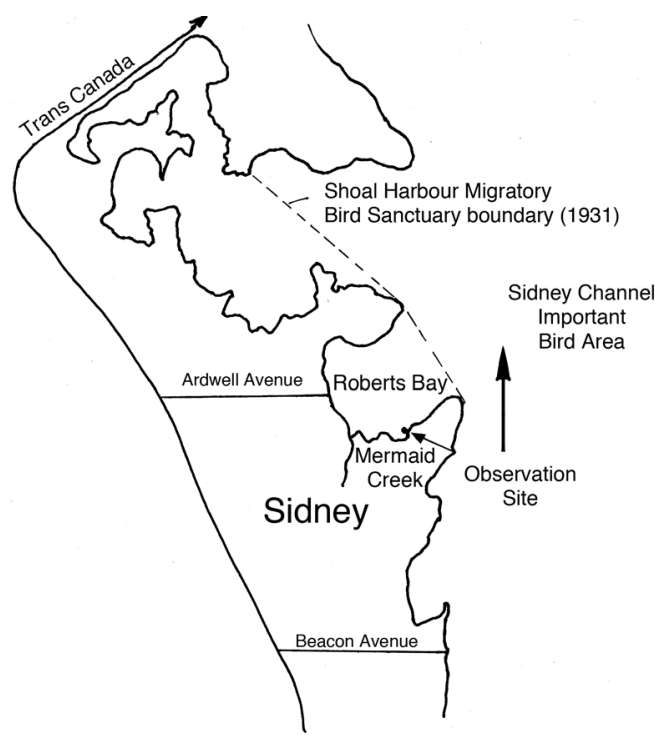

FIGURE 1. Shoal Harbour Migratory Bird Sanctuary in Sidney by the Salish Sea, prime Bufflehead habitat in winter.

perhaps more often during the coldest days of midwinter, and at any time of day. Only once have I observed an eagle take a drake, but it happened under unusual circumstances involving a Peregrine Falcon.

In contrast to their relaxed vigilance toward potential eagle predation, Buffleheads show a heightened alertness to peregrines. On the occasion just mentioned, a peregrine stooped on a flock, causing a panic of diving, and with "split-second" timing, an eagle, that had evidently anticipated the reaction, launched itself from its fir snag and snatched a surfacing drake. Although I recall only a handful of hazings and unsuccessful predation attempts over the years, I suspect that peregrines might be the driving force behind the Bufflehead's precise departure time. This speculation is based on two anecdotes.

The first occurred on 24 November 2000, when a peregrine passed over the bay just before dusk, causing the Buffleheads to remain highly alert, close in, obscured in the shadows of the south shore. When forced to take flight by a pedestrian just before the end of civil twilight, they did so hesitantly and in a notably chaotic "crash-diving" maneuver. At this time the peregrine stooped, missed, and continued pursuing individuals into the darkness. A few Buffleheads returned near shore and remained until it was too dark for me to detect them. I'd seen the Bufflehead's crash-diving evasive tactics before, though not in the presence of a predator. Evidently it was a practised procedure, like the orchestrated flight drills of the Dunlin (Calidris alpina) on the Fraser River delta (Dekker and Ydenberg 2004). The second anecdote happened to be my last data entry (3 February 2007) in 
Departure Time

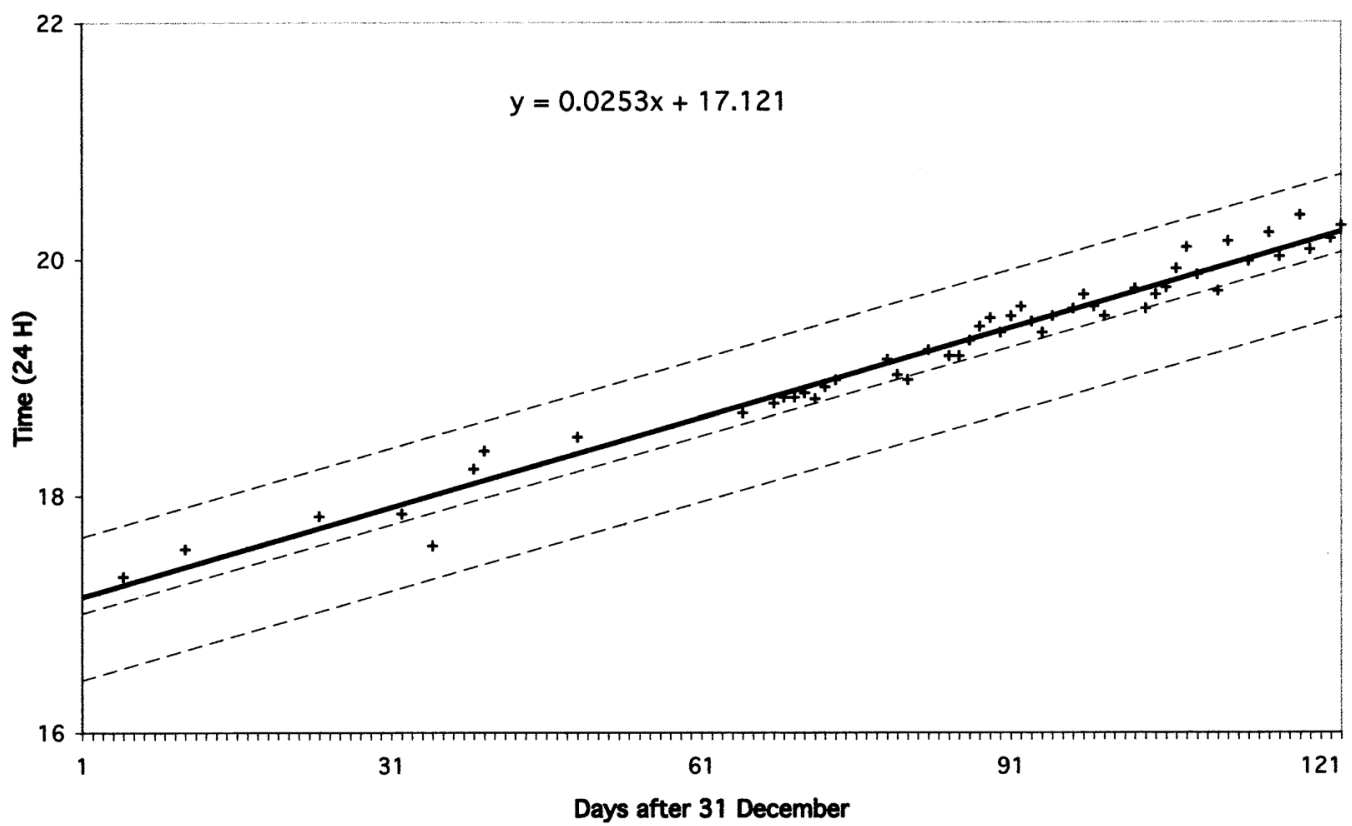

FIGURE 2. Evening departure times of Buffleheads from Shoal Harbour Migratory Bird Sanctuary, January to May 20002007. The single exception before civil twilight involved anti-predator maneuvers. The upper dashed line is nautical twilight, the middle is civil twilights, and the lower is sunset.

Figure 2, the only data point to fall before civil twilight and it was one of the rare occasions when they showed evasive flight tactics. Perhaps it was a practice procedure or maybe they sensed a peregrine.

So why do they depart so precisely after twilight? Once aptly called the Duck Hawk, the peregrine is known to be able to hunt in low light levels, and to take crepuscular species such as the Sora (Porzana caroli$n a$; Nero 2000) and bats. The timing may represent the peregrine's threshold for effective light levels in which to hunt. Peregrines were once more abundant and presumably a much greater threat over eons. Paine et al. (1990) have shown that their recovery has had a marked influence on the structure and integrity of a seabird colony in nearby Washington State. And why, I wonder, do the Buffleheads always depart from one side of the bay? At first I assumed this choice was because the south side was in the lee and around the delta of Mermaid Creek, but now wonder whether it might have more to do with it being on the shaded side of the bay, and their flight trajectory into the darkest horizon within the limits of nautical twilight, less than two feet off the black water, like a Petit Garrot or "Shotbolt".

Although it is thought that Bufflehead populations are not limited by predation (Erskine 1972), this study suggests that predation may strongly shape their behaviour and habitat choice. Just because predation is seldom observed, does not mean that it is not operat- ing in powerful and subtle ways. Although predation pressure and light thresholds might determine the schedule of departures, their daily commute between nocturnal offshore roosting habitat and essential feeding habitat may have evolved due to a complex of other factors.

Where do the Buffleheads go at night? Not far, I believe. On two occasions I've seen some of them land at dusk in adjacent channels of the Gulf Islands, including Sidney Channel "Important Bird Area", a UNESCO-designated site of international importance. This area, including Shoal Harbour Migratory Bird Sanctuary, is presently being evaluated as part of a proposed National Marine Conservation Area. Thus the dual habitat requirements of Buffleheads may be included within a world view.

\section{Acknowledgments}

Dedicated to the late Lionel (Jim) Johnson. Thanks to Bill Griffiths, Tom Murison, and Gavin Johnston for their interest and discussion. Comments by Laura Darling, C. Stuart Houston and A. J. Erskine greatly improved the manuscript.

Documents Cited (marked $*$ in text)

Dawe, N. K. 1982. Use of Shoal Harbour Bird Sanctuary by migratory birds. Unpublished report by Environment Canada, Canadian Wildlife Service, Qualicum Beach, British Columbia, 6 pages, appendices 1-7. 


\section{Literature Cited}

Badzinski, S., R. Cannings, T. Armenta, J. Komaromi, and P. Davidson. 2006. The British Columbia Coastal Waterbird Survey: an evaluation of survey power and species trends after five years of monitoring. Technical Report Series (455). Canadian Wildlife Service Pacific \& Yukon region, and Bird Studies Canada, Delta, British Columbia.

Dekker, D., and R. Ydenberg. 2004. Raptor predation on wintering dunlins in relation to the tidal cycle. Condor 106: 415-419.

Erskine, A. J. 1972. Buffleheads. Canadian Wildlife Service Monograph Series (4). Information Canada, Ottawa. 240 pages.

Eyolfson, J. 2006. The night ducks rained on Foam Lake. Logberg-Heimskringla 120: 12.

Finley, J. K. 2001. The great Bufflehead crash, 1940. Blue Jay 58: 161-167.
Gauthier, G. 1993. Bufflehead, Bucephala albeola. The birds of North America (67). 24 pages. Edited by A. Poole and F. Gill, The Academy of Natural Sciences of Philadelphia. Munro, J. A. 1942. Studies of waterfowl in British Columbia: Bufflehead. Canadian Journal of Research 20: 133-160.

Nero, R. W. 2000. The Peregrine Falcon and the Sora. Blue Jay 58: 125-127.

Paine, R. T., J. T. Wooton, and P. D. Boersma. 1990. Direct and indirect effects of Peregrine Falcon predation on seabird abundance. Auk 107: 1-9.

Swallow, H. S. 1941. Rain of ducks at Foam Lake, Saskatchewan. Canadian Field-Naturalist 55: 130.

Welty, J. C. 1975. The life of birds. Second edition. W. B. Saunders Co., Philadelphia, Pennsylvania. 623 pages.

Received 20 April 2007

Accepted 25 March 2008 